\title{
A Case of Linagliptin-Induced Bullous Pemphigoid
}

\author{
Brenda Carrillo, BS 1 , Natalya M. Gallaga, BS 1 , Paige Hoyer, MD², Lindy Ross, MD², Michael \\ Wilkerson, $\mathrm{MD}^{2}$ \\ ${ }^{1}$ University of Texas Medical Branch School of Medicine, Galveston, TX \\ 2Univeristy of Texas Medical Branch, Department of Dermatology, Galveston, TX
}

\section{ABSTRACT}

Bullous pemphigoid is an autoimmune subepidermal blistering condition in which autoantibodies target components of the hemidesmosomal proteins. It typically presents as pruritic bullous lesions in a generalized distribution. Certain drugs such as diuretics, NSAIDs, antibiotics, and ACE inhibitors have been implicated in the development of bullous pemphigoid. Recently, a class of medications for type II diabetes, dipeptidyl peptidase-4 (DPP-4) inhibitors (commonly called gliptins) have been implicated in drug-induced bullous pemphigoid. We report a case of a 73-year-old female with type II diabetes mellitus who presented with biopsy-proven bullous pemphigoid after being treated with linagliptin. After discontinuing linagliptin and receiving first-line treatment, the patient achieved remission by her five-week follow-up. It is imperative that dermatologists and primary care physicians remain aware of this association when diagnosing and treating bullous pemphigoid, particularly in diabetic patients.

\section{INTRODUCTION}

Bullous pemphigoid (BP) is an autoimmune disease characterized by subepidermal blisters and autoantibodies against hemidesmosomal proteins of the basement membrane, BP 180 and BP 230. ${ }^{1}$ It predominantly affects the elderly and typically presents as tense vesicles and bullae in normal-appearing skin or over erythematous or urticarial plaques. ${ }^{1}$ The bullae later rupture and cause pruritic erosions. ${ }^{1}$ BP can also have atypical variants such as eczematous or urticarial lesions, excoriations from pruritus, or solely pruritus without rash. ${ }^{1}$ Drugs such as furosemide, spironolactone, ibuprofen, topical diclofenac, amoxicillin, ciprofloxacin, ACE inhibitors, TNF-alpha inhibitors, and potassium iodide, among many others, have been implicated in drug-induced BP. ${ }^{1}$ Recently, dipeptidyl peptidase-4 (DPP-4) inhibitors have been increasingly associated with BP. ${ }^{2-8}$ DPP-4 inhibitors are a relatively newer drug class used to treat diabetes mellitus, with the first one, sitagliptin, being approved by the FDA in 2006. ${ }^{2}$ While the mechanism by which they may induce BP is not entirely clear, an association between these has become evident. ${ }^{3,8}$

\section{CASE PRESENTATION}

A 73-year-old woman with a history of diabetes mellitus II and hypertension presented for evaluation of intermittent blisters. She reported the lesions appeared mostly on her scalp, mouth, upper chest, arms, and, occasionally, on her legs (Figure 1). The lesions were associated with a 


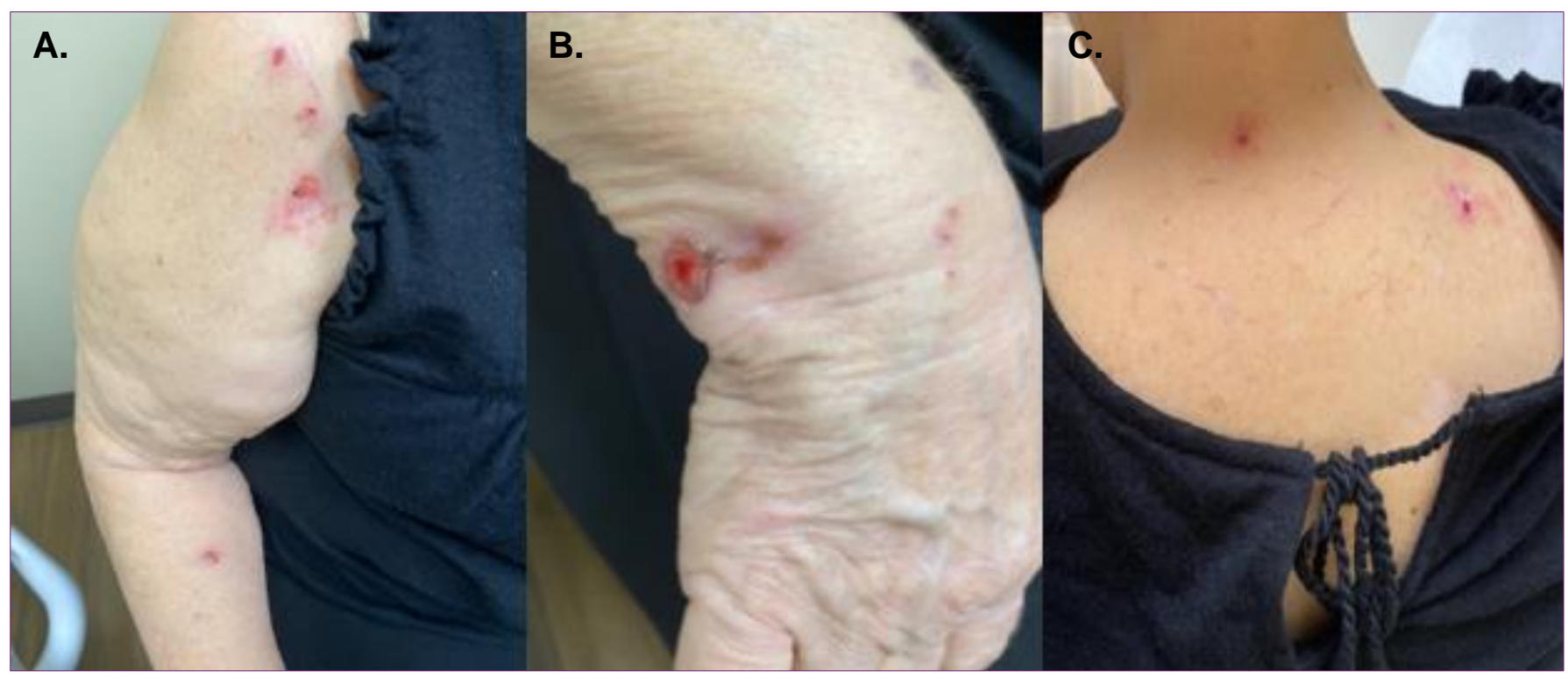

Figure 1. Erythematous erosions on $(A)$ arm, $(B)$ dorsal hand and $(C)$ upper back

"burning" sensation and she experienced pruritus when they "popped".

Her current medications at the time of onset included atorvastatin, carvedilol, insulin detemir, levothyroxine, linagliptin, ramipril, terazosin, aspirin, cholecalciferol, coenzyme q10, docosahexanoic acid/epa, magnesium, milk thistle, vitamin $B$ complex and vitamin K2. A skin biopsy showed subepidermal bullae with eosinophils consistent with bullous pemphigoid. Direct immunofluorescence showed moderate linear $\operatorname{lgG}$ and $\mathrm{C} 3$ at the basement membrane. Drug-induced bullous pemphigoid associated with either linagliptin or ramipril was suspected. Because linagliptin was the most recent drug added to her regimen of the two, it was discontinued and ramipril was continued. The patient was instructed to apply clobetasol $0.05 \%$ cream twice a day to affected areas of the body and $0.05 \%$ fluocinonide gel twice a day to mucosal lesions. She had full resolution of her lesions and pruritus at her five-week follow-up, with no recurrence. Had the lesions not resolved past four months, after allowing sufficient time for IgG antibodies to decay, then discontinuation of the ACE inhibitor would have been attempted.

\section{DISCUSSION}

The patient's remission after discontinuing linagliptin while still on an ACE inhibitor, another drug commonly known to induce $\mathrm{BP}$, suggests this case was likely induced by linagliptin. Cases of gliptin-induced bullous pemphigoid have been reported in various case reports as well as in nationwide studies. A European pharmacosurveillance study showed disproportionate incidence for bullous pemphigoid and vildagliptin, linagliptin, saxagliptin, and sitagliptin. ${ }^{3}$ This study used proportional reporting ratios (PRR) as a measure of disproportionality and found BP was reported relatively more frequently with these agents than with other drugs. Similarly, a Japanese pharmacosurveillance study showed disproportionate incidence between BP and vildagliptin, teneligliptin, and linagliptin in a disproportionality analysis using reporting odds ratios (ROR). ${ }^{4}$ In addition, an Israeli 
Table 1. DPP4-Inhibitor Withdrawal and First-Line Treatment in Gliptin-Induced BP

\begin{tabular}{|c|c|c|c|c|}
\hline & $\begin{array}{c}\text { Benzaken et al. } \\
2018\end{array}$ & $\begin{array}{l}\text { Magdaleno Tapial } \\
\text { et al. } 2020\end{array}$ & $\begin{array}{c}\text { Kridin and Bergman } \\
2018\end{array}$ & Plaquevent et al. 2019 \\
\hline \multicolumn{5}{|l|}{ Patient Demographics } \\
\hline Male/Female & $17 / 11$ & $19 / 12$ & $21 / 15$ & $58 / 50$ \\
\hline Age, years & $\begin{array}{l}<80: n=14 \\
>80: n=14\end{array}$ & $77.71 \pm 8.4(\mathrm{SD})$ & $\begin{array}{c}0-69: n=10 \\
70-79: n=10 \\
>80: n=16\end{array}$ & $77.9 \pm 9.3(\mathrm{SD})$ \\
\hline DPP4-I involved (n) & $\begin{array}{l}\text { Vildagliptin (14) } \\
\text { Sitagliptin (10) } \\
\text { Linagliptin (3) } \\
\text { Saxagliptin (1) }\end{array}$ & $\begin{array}{l}\text { Vildagliptin (12) } \\
\text { Sitagliptin (5) } \\
\text { Linagliptin (13) } \\
\text { Saxagliptin (1) }\end{array}$ & $\begin{array}{c}\text { Vildagliptin (24) } \\
\text { Sitagliptin (6) } \\
\text { Linagliptin (9) } \\
--\end{array}$ & $\begin{array}{c}\text { Vildagliptin (59) } \\
\text { Sitagliptin (44) } \\
-- \\
\text { Saxagliptin (5) }\end{array}$ \\
\hline Treatment & $\begin{array}{l}\text { High-potency } \\
\text { topical steroids, } \\
\text { systemic } \\
\text { corticosteroids if } \\
\text { refractory, followed } \\
\text { by taper }\end{array}$ & Corticosteroids & $\begin{array}{l}\text { PO prednisone } \\
>1 \mathrm{mg} / \mathrm{Kg}(\mathrm{n}=22), \\
\text { adjuvant } \\
\text { immunosuppressant } \\
(\mathrm{n}=15) \text {, topical steroid } \\
(\mathrm{n}=4)\end{array}$ & $\begin{array}{l}\text { High potency topical } \\
\text { corticosteroid, systemic } \\
\text { corticosteroid }\end{array}$ \\
\hline $\begin{array}{l}\text { \#BP Patients } \\
\text { discontinued DPP4-I }\end{array}$ & $19 / 28$ & $27 / 31$ & $19 / 36$ & $48 / 106$ \\
\hline $\begin{array}{l}\text { DPP4-I Discontinuation } \\
\text { Results }\end{array}$ & $\begin{array}{l}\text { Complete }(11 / 19) \\
\text { or partial }(7 / 19) \\
\text { remission }\end{array}$ & $\begin{array}{l}\text { Complete response } \\
\text { (26/27), } 1 \text { death }\end{array}$ & $\begin{array}{l}\text { Complete remission } \\
\text { off therapy }(6 / 19) \text {, } \\
\text { minimal therapy } \\
(9 / 19) \text {, partial } \\
\text { remission }(3 / 19) .1 \\
\text { death }\end{array}$ & $\begin{array}{l}\text { Median } 15 \text { days to } \\
\text { control disease. First } \\
\text { relapse in } 17 / 39 \\
\text { patients with delay of } \\
4.8 \text { months. } 15 \text {-day } \\
\text { delay of disease } \\
\text { control }\end{array}$ \\
\hline $\begin{array}{l}\text { DPP4-I Continuation } \\
\text { Results }\end{array}$ & $\begin{array}{l}1 \text { complete } \\
\text { remission. } \\
4 \text { partial remission. } \\
1 \text { relapse. } 3 \text { deaths. }\end{array}$ & $\begin{array}{l}3 / 4 \text { partial } \\
\text { remission ( } 1 \text { lost to } \\
\text { follow-up) }\end{array}$ & $\begin{array}{l}\text { Complete remission } \\
\text { off therapy }(3 / 13) \text {, } \\
\text { minimal therapy } \\
(4 / 13), 8 \text { deaths }\end{array}$ & $\begin{array}{l}\text { Median } 14 \text { days to } \\
\text { control disease. First } \\
\text { relapse in } 13 / 35 \\
\text { patients with delay of } \\
5.8 \text { months. } 14 \text {-day } \\
\text { delay of disease } \\
\text { control }\end{array}$ \\
\hline Study Conclusions & $\begin{array}{l}\text { DPP4-I withdrawal } \\
\text { (and initiation of } \\
\text { first line treatment) } \\
\text { had favorable } \\
\text { impact }\end{array}$ & $\begin{array}{l}\text { DPP4-I withdrawal } \\
\text { combined with first- } \\
\text { line treatment } \\
\text { results in complete } \\
\text { clinical response in } \\
\text { almost all patients }\end{array}$ & $\begin{array}{l}\text { DPP4-I withdrawal } \\
\text { lead to improved } \\
\text { clinical course }\end{array}$ & $\begin{array}{l}\text { No statistical } \\
\text { significance in delay of } \\
\text { disease control }(p= \\
0.95) \text {, rate }(p=0.63) \text {, } \\
\text { delay of relapse } \\
(p=0.9)\end{array}$ \\
\hline
\end{tabular}

DPP4-I - Dipeptidyl peptidase-4 inhibitor; BP - bullous pemphigoid, SD - standard deviation; PO - per oral

case-controlled cohort study found linagliptin to be significantly associated with BP, although to a lower extent than vildagliptin. ${ }^{5}$

Gliptins, including linagliptin, have been implicated in several individual case reports as well. Latency times have ranged from a few months to more than a year. ${ }^{2}$ Therefore, it is important to consider the possibility of linagliptin-induced bullous pemphigoid even when the patient has been on a gliptin for several years. Furthermore, our patient was in remission after administration of first-line treatment and removal of the gliptin. This is consistent with several other studies. Benzaken et al. found that $95 \%$ of cases achieved remission when the gliptin was removed and first-line treatment was provided. ${ }^{6}$ Magdaleno-Tapial et al. found that $96 \%$ of patients in which the agent was March 2021 Volume 5 Issue 2 
withdrawn were in remission. ${ }^{7}$ One study found that patients in which the agent was removed had a better clinical course that those who continued on the DPP-4 inhibitors. ${ }^{5}$ However, one study found that there was no difference in median time to achieve disease control, rate, or relapse between groups who stopped or continued gliptin use when both groups were treated with corticosteroids. ${ }^{8}$ Because of differences in treatment between the patients in these studies, it is difficult to assess the effectiveness of agent withdrawal alone on patient prognosis. Nevertheless, changing the patient to a different medication may still be worth considering.

Despite the increasing reports of gliptininduced bullous pemphigoid, the exact mechanism is still not clear. DPP-4 inhibitors increase glucagon-like peptide-1 and glucose-dependent insulin-trophic polypeptide, leading to increased insulin release and decreased glucagon secretion. ${ }^{2}$ DPP-4 is expressed in many different cells of the body, including the skin. ${ }^{5}$

It is a plasminogen receptor which can activate plasminogen leading to the activation of plasmin, ${ }^{9}$ which is known to cleave BP180. ${ }^{10}$ Inhibition of DPP-4 may lead to improper cleavage of BP180, possibly changing its capacity to induce an immune response. ${ }^{11}$ Inhibition of DPP-4 may also increase the activity of chemokines, induce eosinophil activation, and subsequently lead to tissue damage. ${ }^{12}$

\section{CONCLUSION}

Due to the increasing number of reported cases of gliptin-induced BP, it is important for physicians to be aware of this association and consider it when encountering a patient with type II diabetes mellitus and bullous pemphigoid. Knowledge of this association can help in assessing patients and considering withdrawal of the gliptin as part of the treatment plan. However, it may be reasonable to attempt treatment of BP with topical steroids prior to discontinuing the gliptin if deemed necessary by the primary care physician.

\section{Conflict of Interest Disclosures: None}

Funding: None

\section{Corresponding Author:}

Brenda Carrillo, BS

Department of Dermatology

University of Texas Medical Branch

301 University Blvd.

4.112, McCullough Building

Galveston, TX, 77550

Phone: 409-772-3376

Email: brecarri@utmb.edu

\section{References:}

1. Bolognia JL, ed. Dermatology: ExpertConsult. 3rd edition ff. Elsevier; 2012. Accessed June 1, 2020. https://www.clinicalkey.com/\#!/browse/book/3s2.0-C20131144449

2. Someili A, Azzam K, Hilal MA. LinagliptinAssociated Alopecia and Bullous Pemphigoid. Eur J Case Rep Intern Med. 2019;6(9):001207001207.

3. García M, Aranburu MA, Palacios-Zabalza I, Lertxundi U, Aguirre C. Dipeptidyl peptidase-IV inhibitors induced bullous pemphigoid: a case report and analysis of cases reported in the European pharmacovigilance database. J Clin Pharm Ther. 2016;41(3):368-370.

4. Arai M, Shirakawa J, Konishi H, Sagawa N, Terauchi Y. Bullous Pemphigoid and Dipeptidyl Peptidase 4 Inhibitors: A Disproportionality Analysis Based on the Japanese Adverse Drug Event Report Database. Diabetes Care. 2018;41(9):e130-e132.

5. Kridin K, Bergman R. Association of Bullous Pemphigoid With Dipeptidyl-Peptidase 4 Inhibitors in Patients With Diabetes: Estimating the Risk of the New Agents and Characterizing the Patients. JAMA Dermatol. 2018;154(10):1152.

6. Benzaquen $\mathrm{M}$, Borradori L, Berbis $\mathrm{P}$, et al. Dipeptidyl peptidase IV inhibitors, a risk factor for bullous pemphigoid: Retrospective multicenter 
case-control study from France and Switzerland. J Am Acad Dermatol. 2018;78(6):1090-1096.

7. Magdaleno-Tapial J, Valenzuela-Oñate $C$, Esteban Hurtado Á, et al. Association Between Bullous Pemphigoid and Dipeptidyl Peptidase 4 Inhibitors: A Retrospective Cohort Study. Actas Dermo-Sifiliográficas Engl Ed. 2020;111(3):249253.

8. Plaquevent M, Tétart F, Fardet L, et al. Higher Frequency of Dipeptidyl Peptidase-4 Inhibitor Intake in Bullous Pemphigoid Patients than in the French General Population. J Invest Dermatol. 2019;139(4):835-841.

9. Gonzalez-Gronow M, Kaczowka S, Gawdi G, Pizzo SV. Dipeptidyl peptidase IV (DPP IV/CD26) is a cell-surface plasminogen receptor. Front Biosci J Virtual Libr. 2008;13:1610-1618.

10. Hofmann SC, Voith U, Schönau V, Sorokin L, Bruckner-Tuderman L, Franzke C-W. Plasmin Plays a Role in the In Vitro Generation of the Linear IgA Dermatosis Antigen LADB97. J Invest Dermatol. 2009;129(7):1730-1739.

11. Izumi K, Nishie W, Mai Y, et al. Autoantibody Profile Differentiates between Inflammatory and Noninflammatory Bullous Pemphigoid. J Invest Dermatol. 2016;136(11):2201-2210.

12. Forssmann U, Stoetzer C, Stephan M, et al. Inhibition of CD26/Dipeptidyl Peptidase IV Enhances CCL11/Eotaxin-Mediated Recruitment of Eosinophils In Vivo. J Immunol.

2008;181(2):1120-1127. 